\title{
Age and reproduction of the southern king croaker Menticirrhus americanus in subtropical South Atlantic environments
}

\author{
Barbara Maichak de Carvalho $^{1}\left(\mathbb{D}\right.$, Alejandra Vanina Volpedo ${ }^{2}$ (D) \& Luís Fernando Fávaro ${ }^{3}$ (iD \\ ${ }^{1}$ Programa de Pós-Graduação em Engenharia Ambiental, Departamento de Engenharia \\ Universidad Federal do Parana, Centro Politécnico, Curitiba, PR, Brasil \\ ${ }^{2}$ Instituto de Investigaciones en Producción Animal, Centro de Estudios Transdisciplinarios del Agua \\ Facultad de Ciencias Veterinarias, Universidad de Buenos Aires, Buenos Aires, Argentina \\ ${ }^{3}$ Laboratório de Reprodução e Comunidade de Peixes, Setor de Ciências Biológicas \\ Departamento de Biologia Celular, Centro Politécnico, Universidade Federal do Paraná, Curitiba, PR, Brasil \\ Corresponding author: Alejandra Vanina Volpedo (avolpedo@gmail.com)
}

\begin{abstract}
Menticirrhus americanus were sampled $(\mathrm{n}=393)$ from two beaches $(\mathrm{P} 1$ is an estuarine beach near the mouth of the Paranaguá Estuarine Complex, and P2 is a beach adjacent to the Paranaguá Estuarine Complex) in the subtropical region of the western South Atlantic waters between August 2015 and June 2016. This study aimed to identify the spawning season and the age structure for $M$. americanus using two sampling methods. For sampling at the P1 beach, seine, line, and pole were used, while samples from the P2 beach were obtained from the artisanal fishers. Females were numerically dominant in all sampling months at both sites except for February when the males became dominant. The species exhibited a protected reproductive season with multiple spawning peaks between August and December. Males and females were captured at all gonadal development stages and ages between 1 and 6 from both sites. At first maturity, the length of the females was $16.3 \mathrm{~cm}$, and the mean age at first maturity was 1.3 years. Individuals aged between 1 and 3 years were dominant $(68 \%)$. The results suggested that young and adults of the $M$. americanus use the same habitats throughout their ontogeny.
\end{abstract}

Keywords: Menticirrhus americanus; estuary; sexual maturity; gill fishing; Sciaenidae

\section{INTRODUCTION}

Intraspecific biological parameters (e.g. age and reproduction) help understand the habitat use of a species (Vaz-dos-Santos et al. 2007, Soeth et al. 2018) and provide important information for decision-making in the implementation of management and conservation plans. Identifying the reproductive period and the first maturity of a fish population helps establish data-based management decisions such as defining closed seasons and determining the mesh sizes that may have a negative impact on the fish populations (Santos et al. 2015). The sex ratio makes it possible to identify if both sexes coexist in the same area and if there is a formation of reproductive aggregates (Lowerre-Barbieri et al. 2016) and the proportion of each sex necessary for the reproduction of the species. Determining the age structure enables scientists to define growth rates for understanding population dynamics (Maciel et al. 2018). Thus, describing the age, growth, and reproductive biology of a species of fisheries population that is impacted by industrial and artisanal fishing provides resource managers with critical information that can be used to establish management tools for protecting longterm population sustainability (Pita et al. 2015, Freitas et al. 2018).

On the southeast-south coast of Brazil, several fisheries target populations of common coastal fish species (Haimovici \& Mendonça 1996, Chaves \& Robert 2003, Andriguetto-Filho et al. 2006). Commercial

Corresponding editor: Yassir Torres 
fisheries utilize several fishing methods, including pair trawling, gillnetting "caceio," and gill fishing (Souza et al. 2007, Alves et al. 2012, Corrêa \& Ávila-da-Silva 2016). The coast of the state of Paraná in southern Brazil is in the South Atlantic's subtropical area. In this coastal area, the most exploited fishery resources are two shrimp species (Xiphopenaeus kroyeri and Farfantepenaeus spp.) captured by trawl fisheries (Graça-Lopes et al. 2002, Souza \& Chaves 2007, Cattani et al. 2011). Due to the low selectivity of the fishing methods used, other species are captured as bycatch (Haimovici et al. 2005, Santos et al. 2016); these include many fish species belonging to the family Sciaenidae (Cattani et al. 2011, Santos et al. 2016).

On the southeast-south coast of Brazil, the family Sciaenidae comprises 26 species that vary in average size from small to large (between 10 and $200 \mathrm{~cm}$ of total length) (Menezes \& Figueiredo 1980). These species mostly occur in shallow water estuarine habitats (Menezes et al. 2003). The sciaenid species range from those with a short life cycle to some that are long-lived (Cardoso \& Haimovici 2011, Militelli et al. 2012, Haimovici et al. 2016, Santos et al. 2017) and use multiple spawning as a reproductive strategy (Braun \& Fontoura 2004, Costa et al. 2015, Carmo-Silva et al. 2016).

The sciaenid, southern king croaker Menticirrhus americanus, is a fish species exploited by recreational anglers and commercial fishers (Souza \& Chaves 2007, Freire et al. 2016). It can reach up to $50 \mathrm{~cm}$ in total length (Cervigón 1993). The species' sale value depends on the specimen's size: the smaller ones are marketed at a lower value, while the larger specimens are filleted and traded for a higher value (Souza et al. 2007, Carvalho comm. pers.). Studies have demonstrated the ecological importance of $M$. americanus as a benthic carnivore (Rondineli et al. 2007, Halunch et al. 2009, Turra et al. 2012) and prey for larger marine predators (Bornatowski et al. 2014). M. americanus is widely distributed in the western Atlantic between latitudes $41^{\circ} \mathrm{N}$ and $51^{\circ} \mathrm{S}$ (Chao et al. 2015).

The spawning season for M. americanus appears to vary with latitude. In the northern Gulf of Mexico, spawning occurs from April to September (Clardy et al. 2014), while in southern Florida, spawning-capable individuals occur from January to November (Herrema et al. 1985). Some studies suggest that adults and juvenile $M$. americanus utilize different habitats (Gianini \& Paiva-Filho 1992, Turra et al. 2012). The species appears to have a short life cycle, reaching up to 6 years of age. Moreover, it exhibits a rapid growth in these few years (McDowell \& Robillard 2013, Clardy et al. 2014) with theoretical maximum longevity of 9.8 years (Gianini \& Paiva-Filho 1992).
Due to this species' ecological and economic importance, the present study focused on characterizing the reproductive seasonality, age, and growth of $M$. americanus in the subtropical site for understanding important life-history parameters, which may aid in future management efforts for this species.

\section{MATERIALS AND METHODS}

\section{Study sites}

Bimonthly samples for Menticirrhus americanus were captured between August 2015 and June 2016 from two sampling sites (P1 and P2) within a single main sampling area located along Brazil's subtropical Atlantic coastal region. P1 is an estuarine beach (with a depth of $2 \mathrm{~m}$ ) near in the mouth of the estuary Paranaguá Estuarine Complex dominated by tides $\left(25^{\circ} 28^{\prime} \mathrm{S}-48^{\circ} 20^{\prime} \mathrm{W}\right)$ and $\mathrm{P} 2$ is a beach adjacent to the estuary on the shallow continental shelf dominated by waves and with an approximate depth of $20 \mathrm{~m}$ in areas of the capture of the specimens $\left(25^{\circ} 36^{\prime} \mathrm{S}-48^{\circ} 28^{\prime} \mathrm{W}\right)$ (Ângulo et al. 2016) (Fig. 1). The main sampling was undertaken within a transitional coastal region between tropical and temperate climates (Spalding et al. 2007).

\section{Sample collection}

At the P1 sampling site, fish samples were collected using beach seines that were $2 \mathrm{~m}$ high, $70 \mathrm{~m}$ long, and had three mesh sizes of $2.5,4$, and $5 \mathrm{~cm}$. During each sampling event, two people dragged the seine at a distance of $20 \mathrm{~m}$ parallel to the coast. At site P1, M. americanus samples were caught by pole and line fishing. At the P2 site, M. americanus were obtained from the artisanal fishers who used a gillnet "caceio" fishing with 6,7 , and $9 \mathrm{~cm}$ stretch mesh size.

Each M. americanus sample was measured for total length $(\mathrm{TL}, \mathrm{cm})$ and total weight $(\mathrm{TW}, \mathrm{g})$. Sagittal otoliths were removed, rinsed, and stored in a dry state for age determination at a later stage. The gonads were removed and weighed (WG, g), then macroscopically examined to determine sex and the reproductive phase. A portion of gonads $(n=162)$ was then preserved in ALFAC ( $80 \%$ alcohol, formaldehyde, and acetic acid) for histological processing.

\section{Reproduction}

Gonads remained in the preservative for a period of 18 to $24 \mathrm{~h}$. The tissues were then processed using a standard methodology for histological paraffin embedding and hematoxylin and eosin Y staining. The histological samples' maturity and reproductive phases were assessed according to a modified version of classification based on Vazzoler (1996) and Brown- 


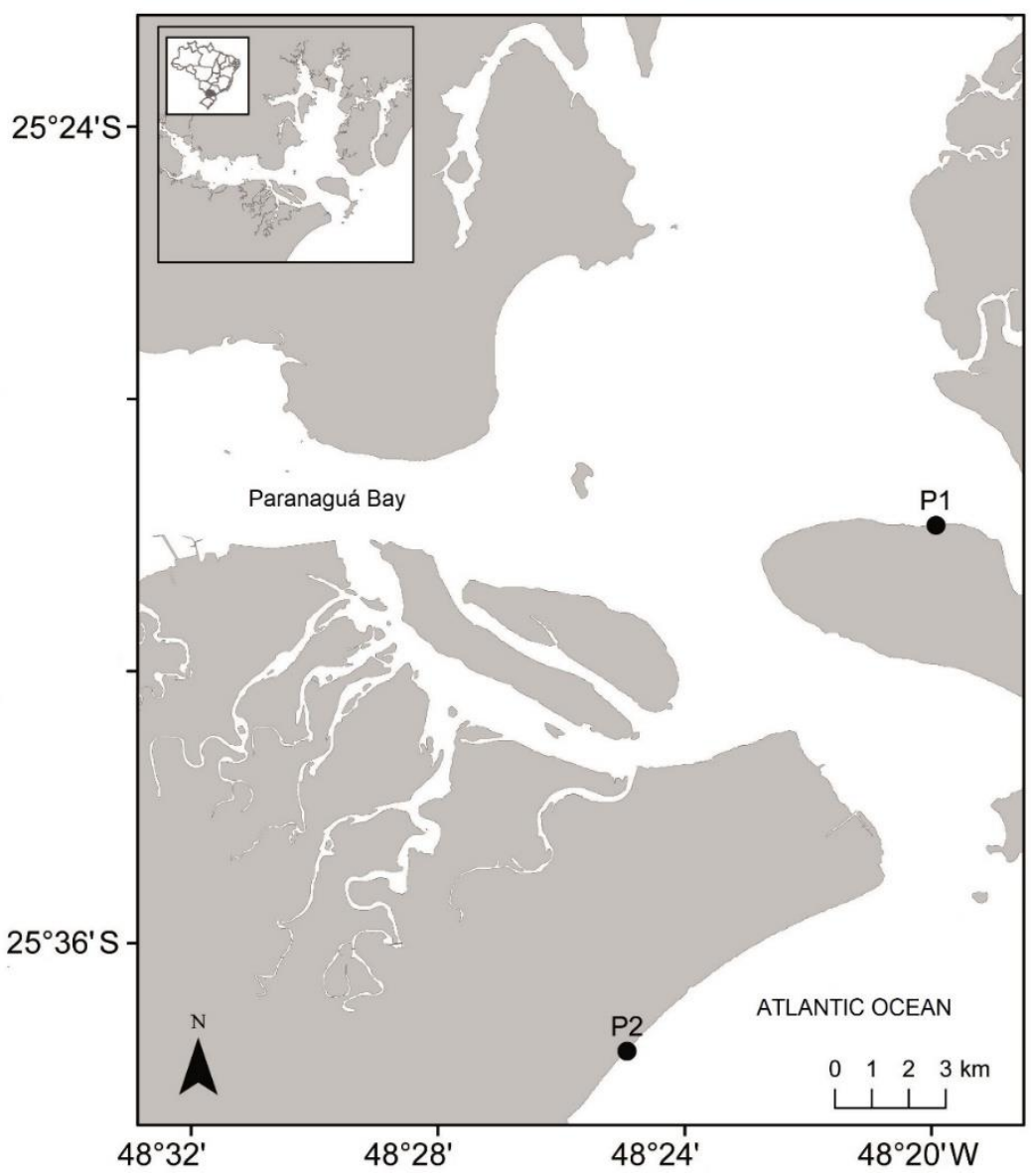

Figure 1. Menticirrhus americanus sampling sites in the subtropical environment of the South Atlantic. P1 is an estuarine beach, and P2 is a small-scale fishery unloading site.

Peterson et al. (2011). The gonadosomatic index (GSI), expressed by the formula GSI $=(\mathrm{WG} / \mathrm{TW}) \times 100$, was determined for each individual. From the individual GSI, the mean GSI was calculated on a bimonthly basis separately for each sex.

\section{Age and growth}

The right sagittal otolith of each specimen was embedded in epoxy resin, cross-sectioned with a lowspeed metallographic saw, and sanded and polished with alumina. Subsequently, the sections were photographed under a polarized-light stereomicroscope for reading the age rings of increments (each increment $=$ one hyaline and one opaque zone; Fig. 2). Three incremental readings were taken for each otolith sample by the same reader at different times. According to McDowell \& Robillard (2013) and Clardy et al. (2014), $M$. americanus forms only one annual ring.

Precision in the number of increment counts from the three readings of each otolith was determined using the coefficient of variance $(\mathrm{CV})$, expressed by the for-

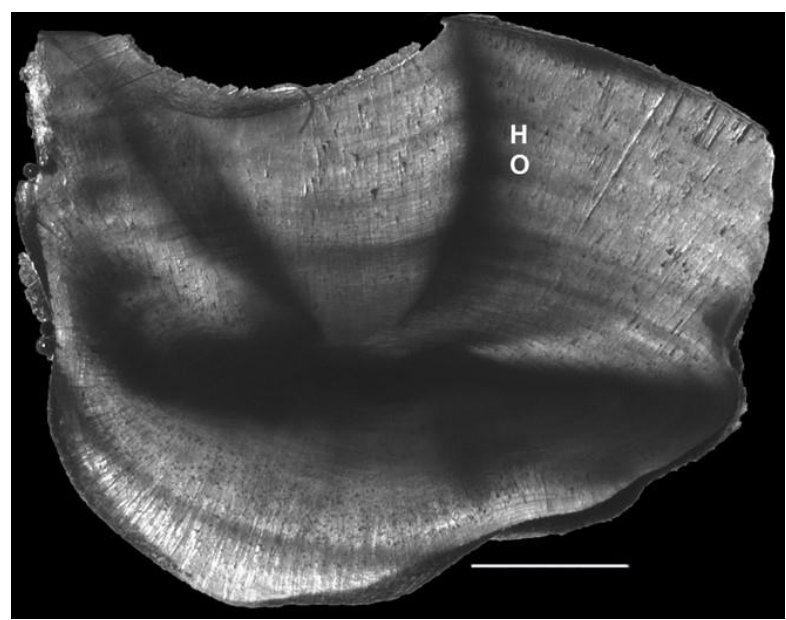

Figure 2. Cross-section of a Menticirrhus americanus otolith (sagitta) collected in the subtropical environment of the South Atlantic. H: hyaline rings, O: opaque rings. Scale: $2 \mathrm{~mm}$.

mula $\left.C V \frac{100}{n} \mid \sum_{=100 n i=1}^{n}\left(\frac{s d i}{\bar{a} i}\right)\right]$, where: $s d i$ is the standard deviation of ages attributed to the individual $i$ and 
$\bar{a} i$ the mean of the readings. After the analyses, the readings that resulted in a coefficient of variance above $8 \%$ were eliminated (Chang 1982).

Growth curves for grouped and separated sexes were obtained by adjusting the mathematical expression of Von Bertalanffy (1938) (VB) where $T L=L_{\infty}\left[1-e^{-k\left(t-t_{0}\right)}\right]$ and by adjusting the Gompertz expression (G) $T L=L_{\infty} \times e\left[-e^{-k\left(t-t_{0}\right)}\right]$. For both expressions, $e$ was the Napierian logarithm, TL: $=$ total length $(\mathrm{cm})$ at age $t ; L_{\infty}:=$ asymptotic length $(\mathrm{cm}), k:=$ instantaneous growth rate, and $\mathrm{t}_{0}:=\mathrm{age}$, at a theoretical length equal to zero (Ogle 2015).

\section{Statistical analyses}

Statistical analysis was performed using the analysis of variance (ANOVA) to verify the TL differences between sexes and sites. The length-weight relationship for each sex was calculated using the following equation (Huxley 1929):

$$
T_{W}=a \times T L^{b}
$$

where $\mathrm{T}_{\mathrm{W}}$ is the predicted total weight, TL the total length, $a$ the coefficient of proportionality, and $b$ the allometric coefficient (Carvalho et al. 2017, Possamai et al. 2018). A paired $t$-test was performed to compare length-weight relationship parameters between sex by sampled location. A chi-square test $\left(\chi^{2}\right)(\alpha=0.05)$ was used to determine if the sex ratio deviated from 1:1.

In order to evaluate the relative health of the samples, the total condition factor $(\mathrm{K})$ and the somatic condition factor $\left(\mathrm{K}^{\prime}\right)$ was expressed respectively by the formulae:

and

$$
\begin{gathered}
K=T_{W} / T_{L}^{b} \\
K^{\prime}=T_{W-} W_{G} / T_{L}^{b}
\end{gathered}
$$

where $b$ is the allometric coefficient of the lengthweight relationship.

The difference between $\mathrm{K}$ and $\mathrm{K}$ ' makes it possible to verify the reproductive process's energy in females and males. A $t$-test was used between the total and the somatic condition factors to check the influence of gonads on each sampling site's condition factor.

The determination of the first maturity length $\left(\mathrm{L}_{50}\right)$ occurred through the logistic curve:

$$
F r=1-\left(e^{-a \times c t m \times b}\right)
$$

where $\mathrm{Fr}$ was the relative frequency of adult individuals; $e$ was the Napierian logarithm; $a$ and $b$ were the coefficients estimated by the least-square method, and $\mathrm{C}_{\mathrm{tm}}$ was the midpoint of the class interval (Possamai \& Fávaro 2015).

The identification of the longevity (A), which corresponds to the time the fish takes to reach $95 \%$ of $\mathrm{L}_{\infty}$ (Santos et al. 2017), was estimated by the Taylor equation (1959):

$$
A=\left(\frac{2.996}{k}\right)+t_{0}
$$

where 2.996 was a constant, $k$ was the instantaneous growth rate, and $t_{0}$ the age at which the fish had a theoretical length equal to zero in the von Bertalanffy curve parameters.

A $t$-test was applied between the parameters of the curve of Von Bertalanffy, Gompertz, and longevity to check for differences in growth rates between males and females. The von Bertalanffy and Gompertz models' adjustment was performed with the 'fish methods (Nelson 2017) and 'FishR' (Ogle 2015) packages in software $\mathrm{R}$. The other statistical analyses were run in software $R$.

\section{RESULTS}

We collected 393 individuals of Menticirrhus americanus: 245 individuals from site P1 and 148 from site P2. The samples of both sexes from P1 presented smaller lengths than those sampled from P2 (Table 1).

Table 1. Parameters of the weight-length relationship of Menticirrhus americanus collected in two subtropical South

\begin{tabular}{|c|c|c|c|c|c|c|c|c|c|c|}
\hline \multirow{2}{*}{ Site } & \multirow{2}{*}{ Sex } & \multirow{2}{*}{$\mathrm{n}$} & \multicolumn{3}{|c|}{$\mathrm{TL}(\mathrm{cm})$} & \multicolumn{2}{|c|}{ Weight (g) } & \multicolumn{3}{|c|}{ Parameter } \\
\hline & & & $\min$ & mean & $\max$ & $\min$ & $\max$ & $\mathrm{a}$ & $\mathrm{b}$ & $\mathrm{R}^{2}$ \\
\hline \multirow{2}{*}{ P1 } & $\mathrm{F}$ & 140 & 12 & 20.34 & 30.9 & 16.5 & 336.53 & $0.001 \pm 0.0058$ & $3.195 \pm 0.041$ & 0.97 \\
\hline & $\mathrm{M}$ & 105 & 12.8 & 17.75 & 29.8 & 15.3 & 206.67 & $0.005 \pm 0.000$ & $3.185 \pm 0.005$ & 0.97 \\
\hline \multirow{2}{*}{$\mathrm{P} 2$} & $\mathrm{~F}$ & 84 & 13.6 & 26.68 & 44.2 & 17.14 & 897.37 & $0.005 \pm 0.00$ & $3.188 \pm 0.035$ & 0.97 \\
\hline & $\mathrm{M}$ & 64 & 14.1 & 27.44 & 33.3 & 18.33 & 347.88 & $0.005 \pm 0.00$ & $3.175 \pm 0.005$ & 0.97 \\
\hline
\end{tabular}
Atlantic environments. F: females, M: males, n: number of individuals, TL: total length $(\mathrm{cm})$ with minimum, mean and maximum, weight $(\mathrm{g})$ with minimum and maximum, b: mean allometric coefficient and standard deviation, a: mean proportionality coefficient and standard deviation, and $\mathrm{R}^{2}$ : coefficient of determination of the weight-length relationship of Huxley (1929). P1: estuarine beach, P2: small-scale fishery unloading site. 
Table 2. The sex ratio of Menticirrhus americanus collected in two subtropical South Atlantic environments. F: number of females, M: number of males, $\mathrm{n}$ : number of individuals, $\chi^{2}$ : chi-square, ${ }^{*} P$-value $<0.05$. P1: estuarine beach, P2: smallscale fishery unloading site.

\begin{tabular}{|c|c|c|c|c|c|c|c|c|}
\hline & \multicolumn{4}{|c|}{$\mathrm{P} 1$} & \multicolumn{4}{|c|}{$\mathrm{P} 2$} \\
\hline Month & $\mathrm{F}$ & $\mathrm{M}$ & F:M & $\chi^{2}$ & $\mathrm{~F}$ & $\mathrm{M}$ & $\mathrm{F}: \mathrm{M}$ & $\chi^{2}$ \\
\hline Aug/15 & 34 & 10 & 3.4 & $13.0 *$ & 15 & 8 & 1.9 & 2.1 \\
\hline Oct $/ 15$ & 35 & 35 & 1.0 & 0.01 & 27 & 11 & 3.4 & $6.7 *$ \\
\hline Dec/15 & 22 & 7 & 3.1 & $7.7 *$ & 15 & 17 & 1.9 & $7.7 *$ \\
\hline $\mathrm{Feb} / 16$ & 20 & 23 & 0.9 & 0.2 & 7 & 13 & 0.9 & 0.1 \\
\hline Apr/16 & 23 & 18 & 1.3 & 0.6 & 9 & 4 & 1.1 & 0.1 \\
\hline Jun/16 & 8 & 11 & 0.7 & 0.4 & 11 & 11 & 1.4 & 0 \\
\hline Total & 142 & 103 & & & 84 & 64 & & \\
\hline
\end{tabular}

Table 3. Microscopic characterization of the stages of ovarian and testicular development of Menticirrhus americanus. Oocytes: PG: primary growth, CA: cortical alveolar, Vtg: primary, secondary and tertiary vitellogenic, GVM: germinal vesicle migration, POF: post-ovulatory follicles, GVBD: germinal vesicle.

\begin{tabular}{|c|c|c|}
\hline \multirow{2}{*}{$\begin{array}{l}\text { Stage of gonadal } \\
\text { development }\end{array}$} & \multicolumn{2}{|c|}{ Microscopic characteristics } \\
\hline & Females & Males \\
\hline Immature & $\begin{array}{l}\text { The ovaries of young females present nests of oogonia } \\
\text { and oocytes in PG. }\end{array}$ & $\begin{array}{l}\text { The testicles present the seminiferous tubules with } \\
\text { reduced light or completely closed. The predomi- } \\
\text { nant cells in this stage are spermatogonia. }\end{array}$ \\
\hline Developing & $\begin{array}{l}\text { The developing ovaries initially present PG oocytes } \\
\text { without cytoplasmic inclusions and CA oocytes, which } \\
\text { present cytoplasmic vesicles. Overdevelopment, more } \\
\text { developed oocytes in different phases of Vtg can be } \\
\text { observed, possibly occurring in a smaller quantity of } \\
\text { GVM oocytes. }\end{array}$ & $\begin{array}{l}\text { Seminiferous tubules partially developed, with } \\
\text { various types of male germline cells. Spermatozoa } \\
\text { absent or in small quantity. }\end{array}$ \\
\hline Spawning-capable & $\begin{array}{l}\text { The ovaries in this stage present a predominance of } \\
\text { GVM and GVBD oocytes; however, PG and Vtg } \\
\text { oocytes are found in smaller numbers. }\end{array}$ & $\begin{array}{l}\text { The testicles present developed seminiferous } \\
\text { tubules with a predominance of spermatozoa. }\end{array}$ \\
\hline Partially-spawned & $\begin{array}{l}\text { This stage occurs only in species that spawn in batches. } \\
\text { POFs and GVM oocytes are present. The initial phases } \\
\text { of oocyte maturation may also be present (PG, Vtg). }\end{array}$ & $\begin{array}{l}\text { Seminiferous tubules with a decreased quantity of } \\
\text { spermatozoa relative to the previous stage. Empty } \\
\text { spaces at the edges of the tubules and a small } \\
\text { quantity of other male germline cells. }\end{array}$ \\
\hline Post-spawning & $\begin{array}{l}\text { Ovaries in the post-spawning stage characterize the end } \\
\text { of the reproductive process, which includes the stages of } \\
\text { "regressing" and "regenerating" described by Brown- } \\
\text { Peterson et al. (2011). POFs and PG oocytes are found } \\
\text { in disorganized ovigerous lamellae. Overdevelopment, } \\
\text { the lamellae reorganize, the POFs are reabsorbed, and } \\
\text { the ovaries start to be constituted by oogonia and PG } \\
\text { oocytes. }\end{array}$ & $\begin{array}{l}\text { Testicles in this stage characterize the end of the } \\
\text { reproductive process, which includes the stages of } \\
\text { "regressing" and "regenerating" described by } \\
\text { Brown-Peterson et al. (2011). The seminiferous } \\
\text { tubules present empty spaces with a small number } \\
\text { of spermatozoa. Testicular replenishment by } \\
\text { sperm line cells in the initial phases of develop- } \\
\text { ment was observed. }\end{array}$ \\
\hline
\end{tabular}

The ANOVA demonstrated significant differences between the TL and sampling sites $(\mathrm{F}=461.3 ; P<$ $0.0001)$ and between the TL and sex $(\mathrm{F}=10.86 ; P=$ 0.001 ). From the relationship, it was possible to state that regardless of the location, $M$. americanus presented a positive allometric growth $(\mathrm{b}>3 ; P<0.05)$ for both sexes (Table 1). The $t$-test between sex by sampling site did not show significant variation $(\mathrm{P} 1, \mathrm{t}=0.42, \mathrm{df}=1$, $P=0.74 ; \mathrm{P} 2, \mathrm{t}=1, \mathrm{df}=1, P=0.5)$.

There was numerical dominance of females at both sampling sites in all months sampled; the exception was observed at both sites in February 2016 and at site P1 in June 2016 (Table 2). The $\chi^{2}$ test detected significant differences in the monthly sex ratio of females and males in August and December for P2 and in October and December for P1 (Table 2).

The gonadal histology allowed the characterization of six stages of oocyte and spermatogonia development. Microscopic analysis of the gonads (Table 3) revealed five phases of ovarian (Fig. 3) and testicular development (Fig. 4). The observation of partially spawned ovaries allowed the characterization of multiple spawning in the species. 


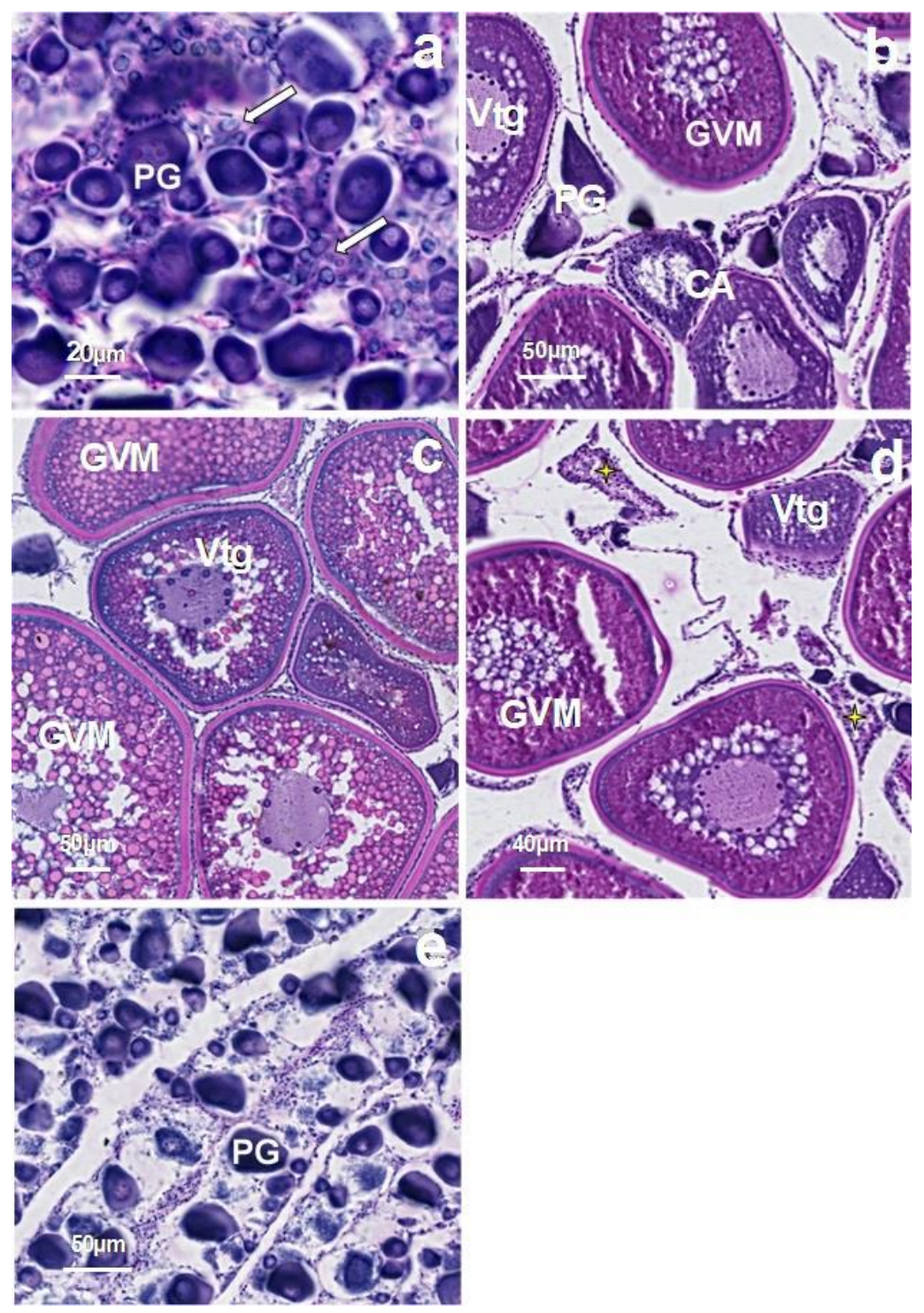

Figure 3. The scale of ovarian development. Microscopic analysis of the ovaries of Menticirrhus americanus in a subtropical environment of the South Atlantic. a) Immature ovary: the white arrows show initial development cells in the process of cellular division, associated with primary growth oocytes (PG), b) developing ovary: oocytes in different phases of development: PG: primary growth, CA: cortical alveolar, Vtg: vitellogenic, GVM: germinal vesicle migration, c) spawning capable ovary: predominance of oocytes in a higher degree of development (Vtg and GVM), d) partially spawned ovary: predominance of oocytes in a higher degree of development, associated with post-ovulatory follicles (POFs) (yellow star), e) post-spawning ovary: disorganized ovigerous lamellae containing oocytes in initial development phases (PG) associated with conjunctive tissue.

The bimonthly mean GSI values showed synchronization in the gonadal development of males and females at both sites: from October to December at site P1 (Figs. 5-6) and a more intense reproductive period October to February at site P2 (Fig. 6). A reduction in the mean GSI was observed at both locations from February (Figs. 5-6).

The percentage frequency of the stages of gonadal development from the histological analysis showed that females in all gonadal stages were captured from both the sampling sites. However, there was a higher occurrence of immature females at P1 relative to $\mathrm{P} 2$ and a predominance of partially spawned and post-spawned females between December and April at both sites (Figs. 5a, 6a).

Immature males were caught only from site P1; partially spawned and post-spawning males were more frequent from February to June. These males were histo- 

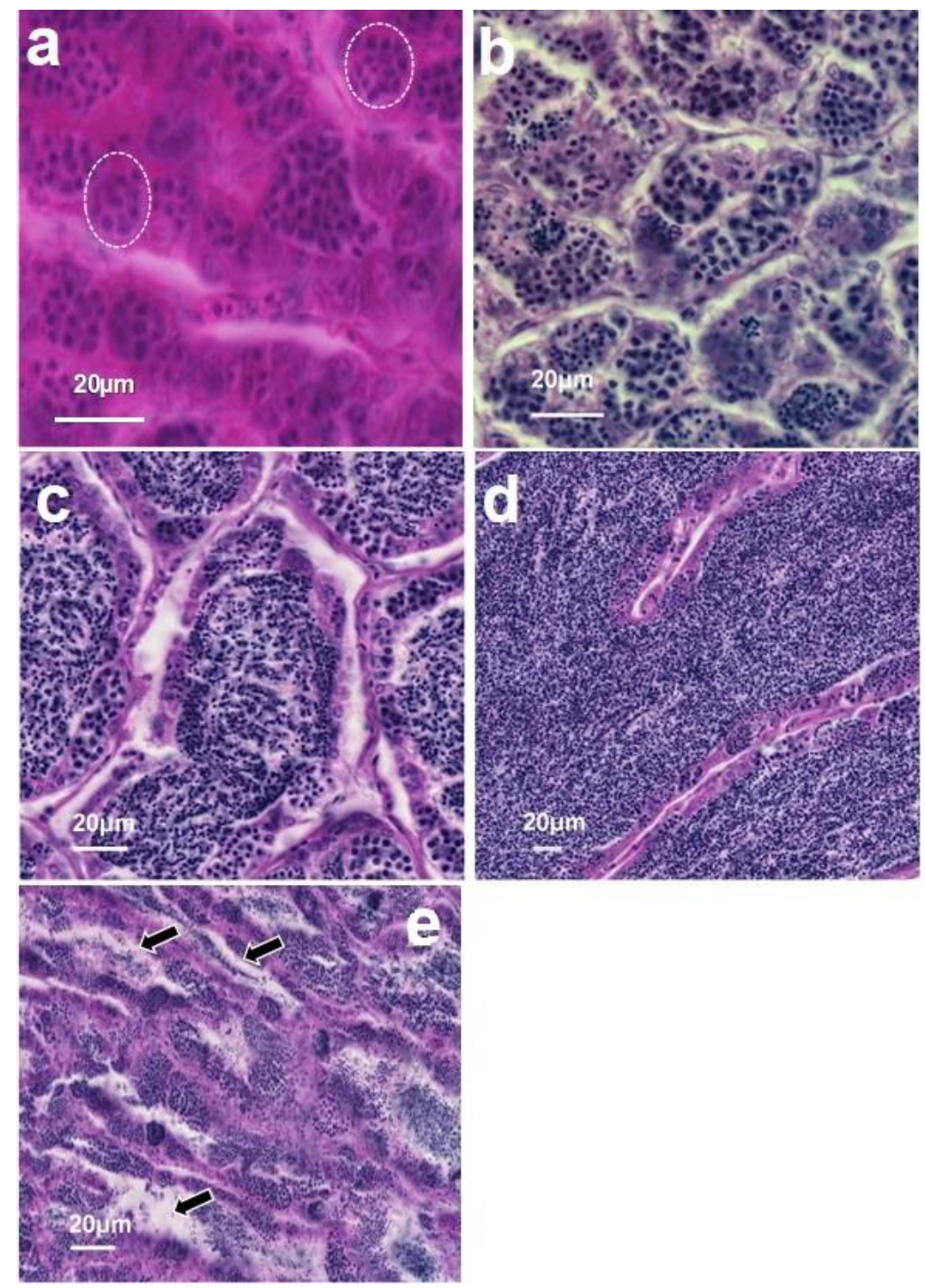

Figure 4. Scale of testicular development. Microscopic analysis of the testicles of Menticirrhus americanus in a subtropical environment of the South Atlantic. a) Immature testicle: circle delimits seminiferous tubules containing spermatogonia, b) developing testicle: the seminiferous tubules present different cell types of the spermatic lineage, c-d) spawning capable testicle: seminiferous tubules practically replete with spermatozoa, e) partially spawned testicle: arrows indicate empty spaces due to elimination of spermatozoa.

logically characterized by a decrease in sperma-tozoa's number corroborating with the decrease in the mean values of GSI in that period (Figs. 5b, 6b).

The total condition factor $(\mathrm{K})$ and the somatic condition factor $\left(K^{\prime}\right)$ presented higher values between August and October 2015 for males at both sites (Figs.7a-b); showed a second peak in February at site P2 alone (Fig.7a). For females, higher values of $\mathrm{K}$ and $\mathrm{K}^{\prime}$ were found between August and October at both the sampling sites, demonstrating higher energy expenditure with the maturation of the gonads (Figs.7a-b). The $t$-test between $\mathrm{K}$ and $\mathrm{K}$ ' for females was not significant for $\mathrm{P} 1(\mathrm{t}=2.2, \mathrm{df}=5, P>0.005)$. It was different for site $\mathrm{P} 2$, where the $t$-test was significant between $\mathrm{K}$ and $\mathrm{K}^{\prime}(\mathrm{t}=7, \mathrm{df}=5, P<0.005)$. However, the $t$-test between $\mathrm{K}$ and $\mathrm{K}^{\prime}$ for males showed significant differences between these parameters at both $\mathrm{P} 1(\mathrm{t}=3.16, \mathrm{df}=5, P$ $<0.005)$ and $\mathrm{P} 2(\mathrm{t}=5, \mathrm{df}=5, P<0.005)$.

The $\mathrm{L}_{50}$ for females was $16.3 \mathrm{~cm}$, and $\mathrm{L}_{100}$ was 22.5 $\mathrm{cm}$ (Fig. 8). The age estimated by counting the rings of $M$. americanus characterized the population of this species aged between 1 and 6 years to be between 1 and 3 years (68\%) (Table 4); the females showed a maximum age of 6 years, and the males of 5 years (Table 5). 

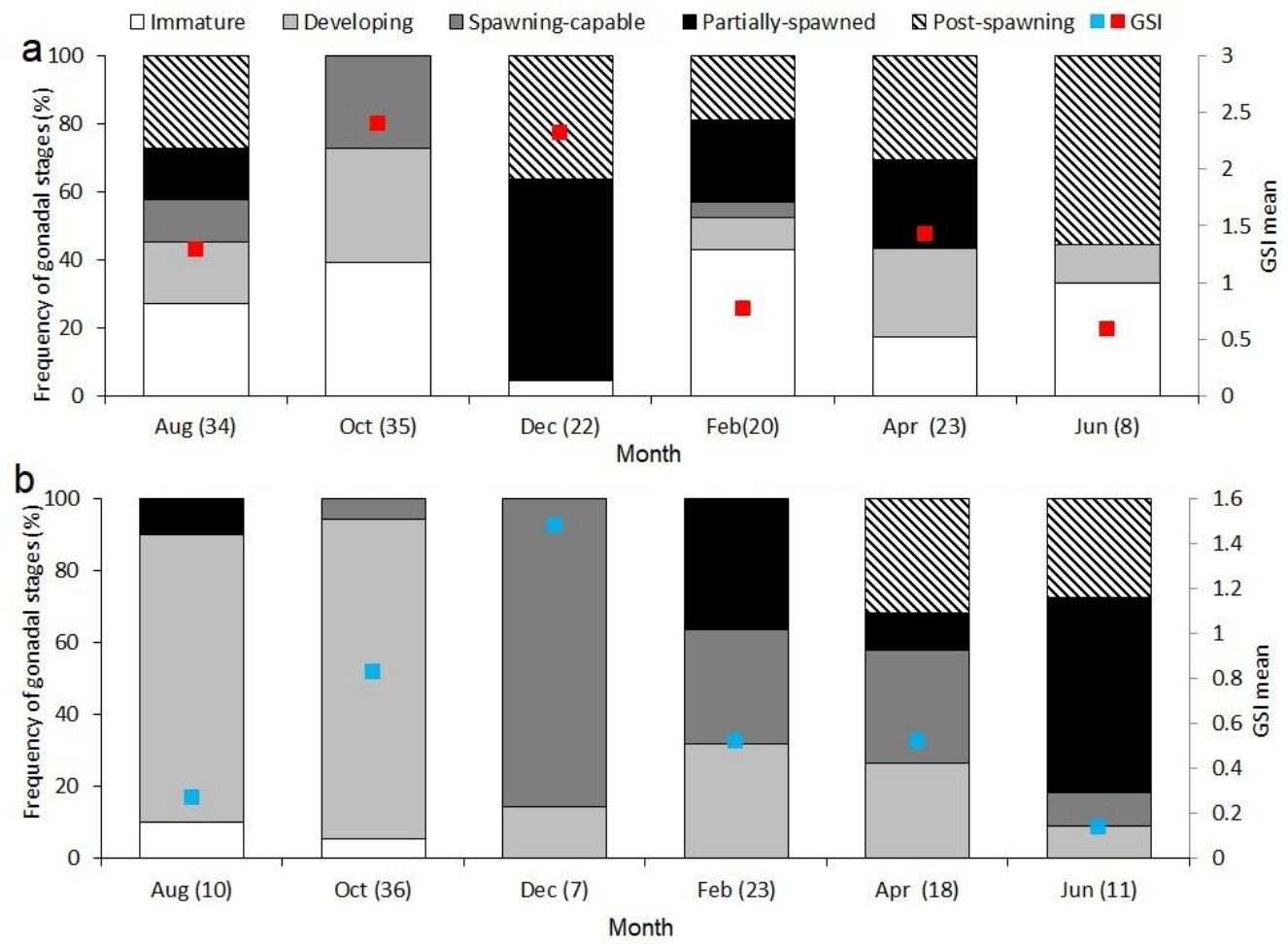

Figure 5. Frequency of occurrence of gonadal maturation phases and gonadosomatic index of Menticirrhus americanus a) females and b) males collected bimonthly in a subtropical environment of the South Atlantic, at site P1 (estuarine beach). (n): number of individuals by month.
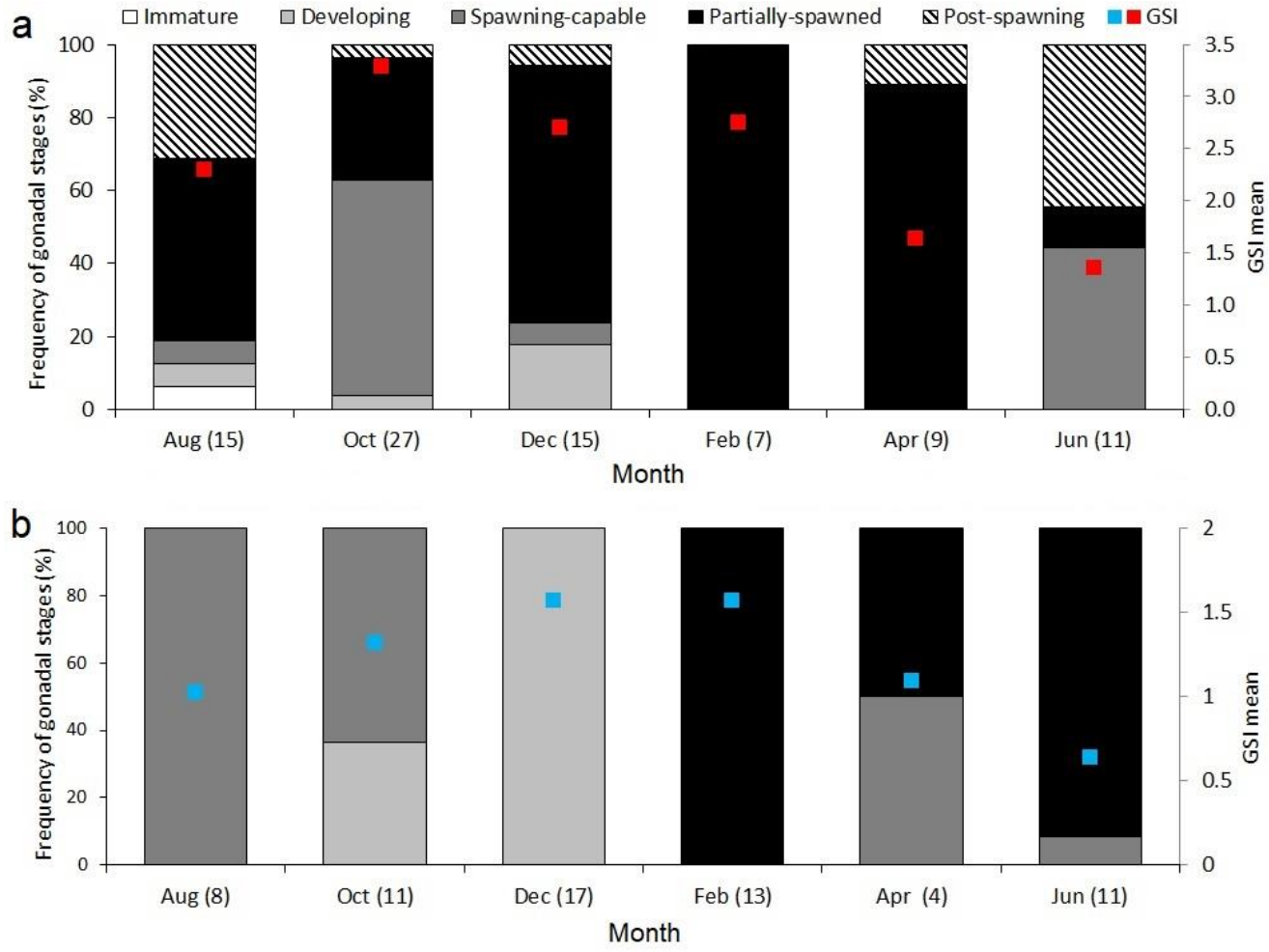

Figure 6. Frequency of occurrence of gonadal maturation phases and gonadosomatic index of Menticirrhus americanus a) females and b) males collected bimonthly in a subtropical environment of the South Atlantic, at site P2 (small-scale fishery). (n): number of individuals by month. 

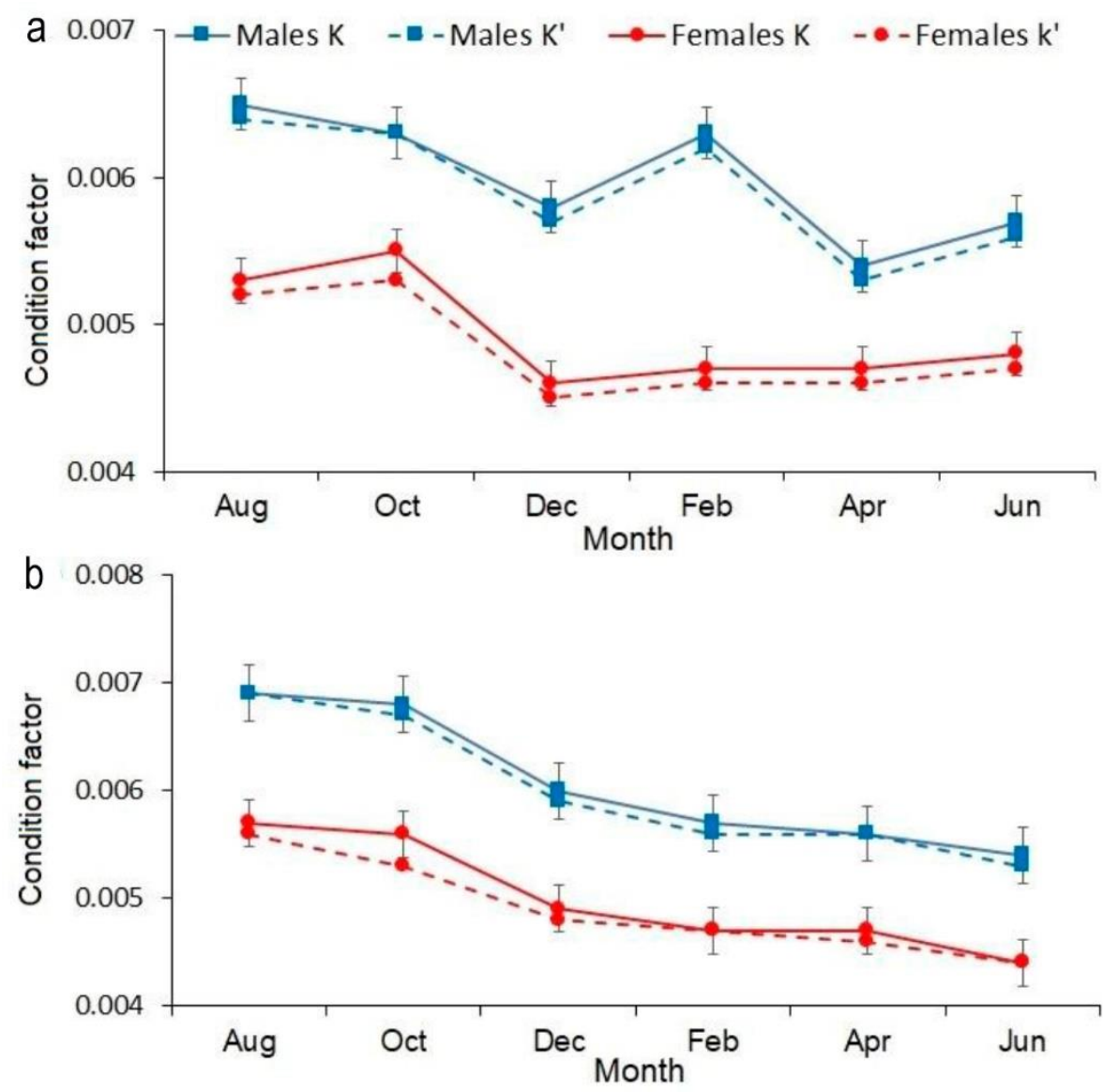

Figure 7. The total condition factor $(\mathrm{K})$ and the somatic condition factor $\left(\mathrm{K}^{\prime}\right)$ of Menticirrhus americanus males and females collected bimonthly in a subtropical environment of the South Atlantic. a) P2: small-scale fishery unloading site and b) P1: estuarine beach.

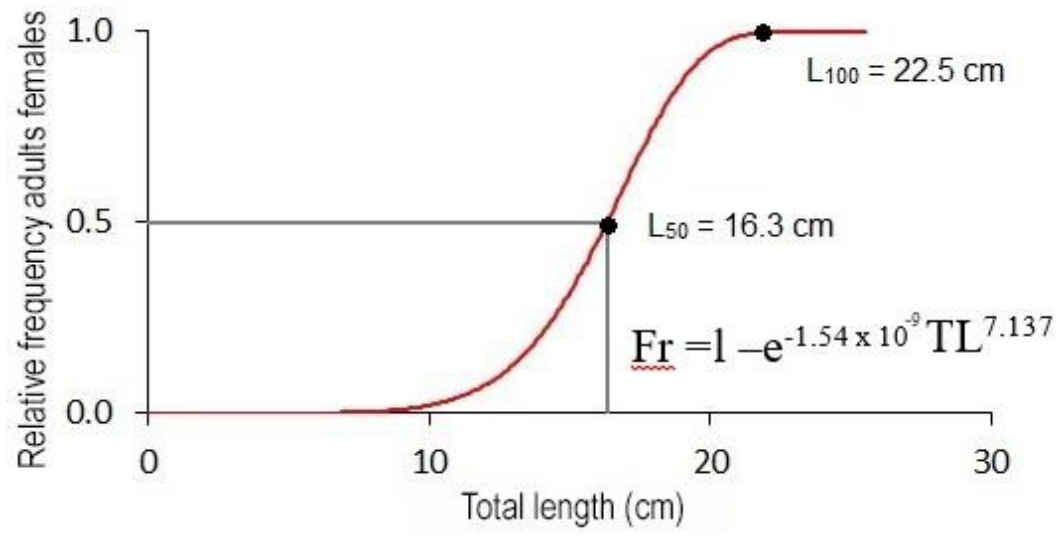

Figure 8. First maturation length of Menticirrhus americanus females collected bimonthly in a subtropical environment of the South Atlantic.

Specimens aged between 1 to 6 years were caught at both sites (Figs. 9a-9b). There was a predominance of specimens of ages between 1 and 2 years (66\%) in P1 (Fig. 9a). In P2, there was a predominance of specimens of ages between 3 and 4 years (63\%) (Fig.
$9 \mathrm{~b})$. The highest percentage of hyaline edge occurs in April 2016 (Fig. 9c).

We observed different values of the growth parameters for grouped sexes (Fig. 10a). The growth parameters for the females and males (Figs. 10b-c). 
Table 4. Age by size class in Menticirrhus americanus collected bimonthly in a subtropical South Atlantic environment.

\begin{tabular}{cllllllc}
\hline \multirow{2}{*}{ Interval class $(\mathrm{cm})$} & \multicolumn{7}{c}{ Age (years) } \\
\cline { 2 - 8 } & 1 & 2 & 3 & 4 & 5 & 6 & Total \\
\hline $11-15$ & 15 & 9 & & & & & 24 \\
$16-20$ & 5 & 21 & 1 & 1 & & & 28 \\
$21-25$ & 2 & 19 & 12 & 15 & & & 48 \\
$26-30$ & & 1 & 25 & 11 & 13 & 1 & 51 \\
$31-35$ & & & 1 & 8 & 5 & 1 & 15 \\
$35-40$ & & & & & & 2 & 2 \\
Total & 22 & 50 & 39 & 35 & 18 & 4 & 168 \\
\hline
\end{tabular}

Table 5. Age by sex in Menticirrhus americanus collected bimonthly in a subtropical South Atlantic environment. F: females, M: males, n: number of individuals by age/sex, TL: total length $(\mathrm{cm}) \pm$ standard deviation (SD).

\begin{tabular}{lcccccrr}
\hline \multirow{2}{*}{ Sex } & \multicolumn{7}{c}{ Age $(\mathrm{n}, \mathrm{TL} \pm \mathrm{SD})$} \\
\cline { 2 - 7 } & 1 & 2 & 3 & 4 & 5 & 6 & Total \\
\hline $\mathrm{F}$ & $18(16.4 \pm 2.7)$ & $22(19.6 \pm 3.8)$ & $22(26.2 \pm 3.1)$ & $19(29.6 \pm 3.4)$ & $9(29.6 \pm 3.4)$ & $2(33.9 \pm 6.4)$ & 92 \\
$\mathrm{M}$ & $14(16.1 \pm 1.9)$ & $28(19.1 \pm 3.3)$ & $21(25.3 \pm 3.9)$ & $16(26.7 \pm 3.9)$ & $10(28.9 \pm 1.9)$ & 89 & 18 \\
\hline Total & 32 & 50 & 43 & 35 & 19 & 2 \\
\hline
\end{tabular}

Taylor's longevity was 11.27 years for grouped sexes, 12.30 years for females, and 10.27 years for males. The $t$-test of the growth curve parameters of Von Bertalanffy, Gompertz, and longevity for males and females showed no significant differences between sexes $(\mathrm{t}=1.37, \mathrm{df}=6, P>0.005)$. The mean age $\left(\mathrm{A}_{50}\right)$ in which $50 \%$ of females were adults was 1.3 years, and $100 \%$ occurred at 3.8 years.

\section{DISCUSSION}

The greater length of females than males was also evidenced by other researchers (Muniz \& Chaves 2008, Haluch et al. 2011, Clardy et al. 2014) and is considered a frequent feature in teleosts (Fávaro et al. 2003, Braun \& Fontoura 2004, Santos et al. 2015), due to the need to allocate female gonads that are larger than the male gonads (Vazzoler 1996). According to Alves et al. (2012), M. americanus females capable of spawning present an increased volume of the coelomic cavity and become more susceptible to capturing in the gillnet fishery. Therefore, females are more vulnerable to gill fishing during periods of higher spawning intensity than males. Moreover, this may be why the imbalance in the sex ratio and the consequent recruitment of this species increased fishing effort using these gears.

At both sites, females were numerically dominant between August and December; a shift of dominance was observed in February when males became dominant. This alternation was also observed by Muniz
\& Chaves (2008). In other species belonging to the family Sciaenidae, a numerical predominance of males was observed, suggesting that variation in the sex ratio was an intraspecific parameter (Braun \& Fontoura 2004, Santos et al. 2015).

Multiple spawning of $M$. americanus had already been described by other authors (Haluch et al. 2011, McDowell \& Robillard 2013, Clardy et al. 2014). Thus, our results confirm the phenomenon of multiple spawning and register individuals reproducing throughout the year in both locations, as demonstrated by the highest $\mathrm{K}$ and $\mathrm{K}^{\prime}$ values between August and October. The highest frequency of specimens in reproductive activity occurred in the hotter periods (spring and summer) that coincided with the period of increase in the primary and secondary productivity in the studied area (Lana et al. 2001) and favored reproductive success. Thus, our results are corroborated by the increase in the abundance of post-flexion larvae of $M$. americanus, observed by Godefroid et al. (2001), during the fall in the same study area.

Determining the first maturity length is important for managing fishery resources regulating the mesh size allowed for fishing, and preventing immature individuals from getting caught (Santos et al. 2015). The first maturity length obtained for $M$. americanus females in this study was close to that calculated by other authors who worked at similar latitudes (Halunch et al. 2011, Clardy et al. 2014). However, near the southern distribution limit of M. americanus, there is an 


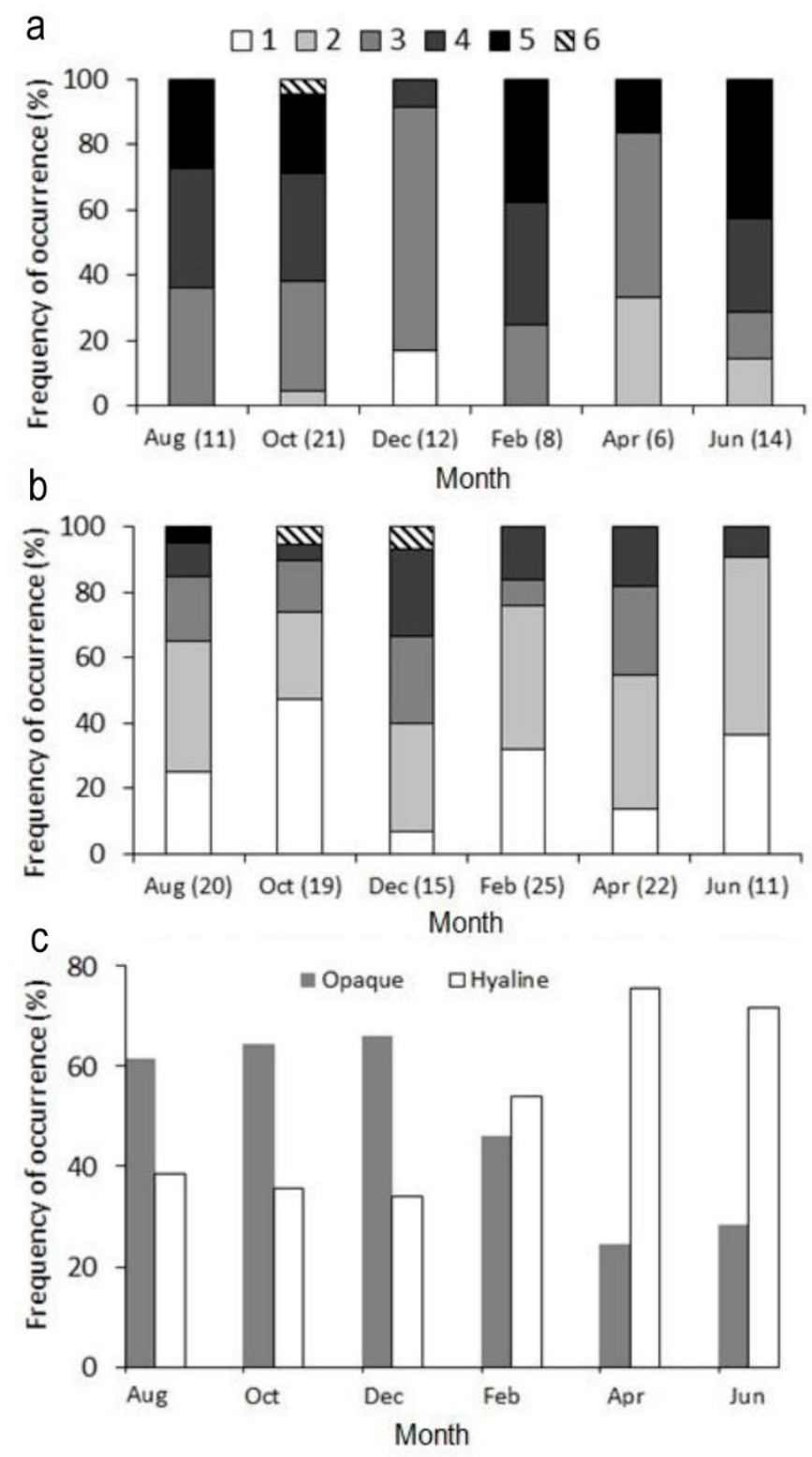

Figure 9. Monthly frequency of occurrence of the ages of Menticirrhus americanus. a) P1 (estuarine beach), b) P2 (smallscale fishery), c) percentage of opaque and hyaline edges in the sections of the otoliths of M. americanus collected bimonthly in the South Atlantic's subtropical environment. (n): number of individuals by month.

increase in the $\mathrm{L}_{50}$ value for both sexes, suggesting gonadal maturation at longer lengths influenced by the lower water temperature (Militelli et al. 2012; L 50 females $=22.2 \mathrm{~cm}$ ). The reduced capture of immature male specimens made it impossible to determine the $\mathrm{L}_{50}$ for males in this study. This observation corroborates that males of this species mature with lower average lengths than females, as observed for other Sciaenidae fish (Santos et al. 2015).

Regarding age determination, studies performed at higher latitudes obtained individuals with a maximum age lower than observed in this study (McDowell \&
Robillard 2013, Clardy et al. 2014); this may be a sampling method effect selecting only one age range. Nevertheless, regardless of the latitude and the sampling method, individuals aged $\leq 3$ years were dominant in the analyzed environments; the age group was more representative in different populations of $M$. americanus (McDowell \& Robillard 2013, Clardy et al. 2014). The variability in length among all ages of $M$. americanus (Table 5) indicates different individual growth rates. Moreover, this is a characteristic of species with split spawning that invest a great amount of energy in gonadal development. A similar observation 

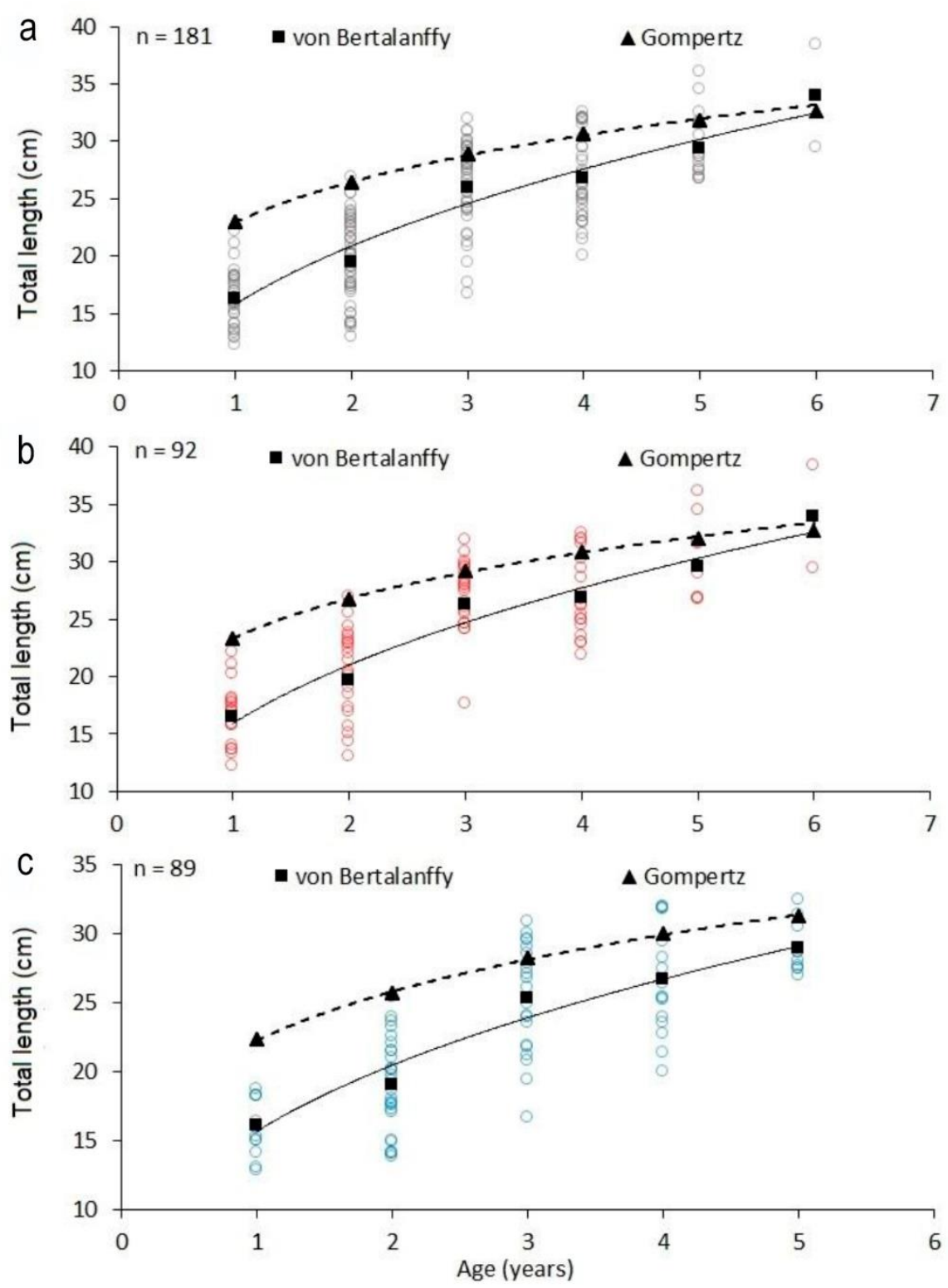

Figure 10. Growth curve fitted according to the von Bertalanffy and Gompertz model for a) grouped sexes b) females and c) males of Menticirrhus americanus collected bimonthly in a subtropical environment of the South Atlantic. The circles indicate the specimens.

was made by other authors (Santos et al. 2017, Maciel et al. 2018, Soeth et al. 2018). Spatially, in this study, younger individuals were dominant (1-2 years) at P1. At $\mathrm{P} 2$, individuals were dominant between 3 and 4 years because of selecting gillnet fishing as the capture method, wherein specimens of larger ages are captured.

Other studies corroborate the positive allometric growth of both sexes of $M$. americanus in these localities. It demonstrates that this species grows more in weight than in length in subtropical latitudes (Haluch et al. 2011, Passos et al. 2012, Dias et al. 2014, Vaz-
dos-Santos \& Gris 2016). Growth curve parameters and longevity also differed between the studies that analyzed M. americanus at different latitudes (Gianini \& Paiva-Filho 1992, McDowell \& Robillard 2013, Clardy et al. 2014, present study). According to Taylor (1959), variations in growth rates, longevity, and von Bertalanffy growth curve parameters are expected along a latitudinal gradient due to different environmental influences suffered by the species, mainly through the water temperature. Species of fish exposed to lower temperatures at higher latitudes tend to grow 
more slowly than individuals of the same species exposed to higher temperatures at lower latitudes, which justifies the different values of the parameters obtained for $M$. americanus since different studies were performed at different latitudes (Gianini \& Paiva-Filho $1992-23^{\circ} \mathrm{S}$, McDowell \& Robillard $2013-31^{\circ} \mathrm{N}$, Clardy et al. $2014-30^{\circ} \mathrm{N}$, present study - $25^{\circ} \mathrm{S}$ ). Despite environmental influence, there is a pattern in the $t_{0}$ values being negative in all studies (Table 1). The lower the value of $t_{0}$, the faster the growth is in the early stages (King 1995), demonstrating that the need to grow rapidly is independent of the environmental forces.

The differences obtained in the size, age, and frequency of the life stages of the specimens captured between the sites demonstrate an influence of the sampling method's selectivity; this was also observed in M. americanus by Muniz \& Chaves (2008). Despite the differences generated by the sampling methods, our results suggest that the occurrence of individuals of all lengths, sexes, ages, and maturity stages at both sites indicates an absence of differentiation of the habitat use. From our results, it is possible to affirm that the gill fishing practiced in the sampled area can impact the population of $M$. americanus since the females capable of spawning were more vulnerable to this kind of fishing in the season of greater spawning intensity.

Fish landing statistics for the genus Menticirrhus from Brazil's southeast-south region recorded landings of approximately 270 t between 2011 and 2014 (ICMBIO 2019, Gep-UNIVALI 2019). At present, it is estimated that the capture of large sciaenids has reduced by approximately $20 \%$ in a decade (Chao et al. 2015). The possible reduction in large sciaenids' stocks will generate the need to explore new fishing resources, resulting in overexploitation of the stock of species belonging to the genus Menticirrhus. It is advisable to create public policies that regulate $M$. americanus fishing since young and adult individuals are currently caught with several types of fishing gear from industrial to sportive fishing (Souza et al. 2007, Muniz \& Chaves 2008, Cattani et al. 2011, Freire et al. 2016).

The study of the biological parameters of $M$. americanus helps to understand the use of the coastal area (continental shelf and estuary) by the species and provides subsidies for monitoring this resource. This study also helps in decision-making for sustainable management. The results obtained are of great importance because this species is commercially exploited on the South Atlantic coast, besides being a bycatch of the shrimp fishery.

\section{ACKNOWLEDGMENTS}

The authors are grateful for funding from the project CAFP-BA/SPU and 292/14 UFPR/Fundação Araucária. They also thank CONICET (PIP112-20120100543 CO), Universidad de Buenos Aires (UBACYT 20020 150100052BA), Agencia Nacional de Promoción Científica y Técnica (ANPCyT PICT 2015-1823); CNPQ for the Ph.D. degree scholarship to the first author (CNPQ 141267/2015-1) and grants postdoctoral provided to BMC (CNPQ 153090/2019-7).

\section{REFERENCES}

Alves, P.M.F., Arfelli, C.A. \& Tomás, A.R.G. 2012. Selectivity of bottom gillnet of southeastern Brazil. Boletim do Instituto de Pesca, 38: 275-284.

Andriguetto-Filho, J.M., Chaves, P.T., Santos, C. \& Liberati, A.S. 2006. Diagnóstico da pesca no litoral do estado do Paraná. In: Isaac V.J., Martins, A.S., Haimovici, M. \& Andriguetto-Filho, J.M. A pesca marinha e estuarina do Brasil no início do século XXI: recursos, tecnologias, aspectos socioeconômicos e institucionais. Universidade Federal do Pará, Belém, pp. 117-140.

Ângulo, R.J., Borzone, C.A., Noernberg, M.A., Quadros, C.J.L., Souza, M.C. \& Rosa, L.C. 2016. The State of Paraná beaches. In: Short, A.D. \& Klein, A.H. (Eds.). Brazilian beach systems. Springer, Berlin, pp. 419463.

Bornatowski, H., Braga, R.R., Abilhôa, V. \& Corrêa, M.F.M. 2014. Feeding ecology and trophic comparisons of six shark species in a coastal ecosystem off southern Brazilian. Journal of Fish Biology, 85: 246263. doi: $10.1111 / \mathrm{jfb} .12417$

Braun, A.S. \& Fontoura, N.F. 2004. Reproductive biology of Menticirrhus littoralis in southern Brazil (Actinopterygii: Perciformes: Sciaenidae). Neotropical Ichthyology, 2: 31-36. doi: 10.1590/ S167962252004000100005

Brown-Peterson, N.J., Wyanski, D.M., Saborido-Rey, F., Macewicz, B.J. \& Lowerre-Barbieri, S.K. 2011. A standardized terminology for describing reproductive development in fishes. Marine and Coastal Fisheries, 3: 52-70. doi: 10.1080/19425120.2011.555724

Cardoso, L.G. \& Haimovici, M. 2011. Age and changes in growth of the king weakfish Macrodon atricauda (Günther, 1880) between 1977 and 2009 in southern Brazil. Fisheries Research, 111: 177-187. doi: 10.1016/ j.fishres.2011.06.017

Carmo-Silva, J.P., Costa, M.R., Gomes, I.D. \& Araújo, F.G. 2016. Gonadal development and fecundity of the smooth weakfish Cynoscion leiarchus (Teleostei: Perciformes: Sciaenidae) in a tropical Brazilian bay. 
Zoologia, 33: 1-9. doi: 10.1590/s1984-4689zool-201 60032

Carvalho, B.M., Barradas, J.R.S., Fontoura, N.F. \& Spach, H.L. 2017. Growth of the silverside Atherinella brasiliensis in a subtropical estuary with some insights concerning the weight-length relationship. Anais da Academia Brasileira de Ciências, 89: 1-12. doi: 10.1590/0001-3765201720160784

Cattani, A.P., Santos, L.O., Spach, H.L., Budel, B.R. \& Gondim-Guanais, J.H.D. 2011. Avaliação da ictiofauna da fauna acompanhante da pesca do camarão sete-barbas do município de Pontal do Paraná, litoral do Paraná, Brasil. Boletim do Instituto de Pesca, 37: 247-260.

Cervigón, F. 1993. Los peces marinos de Venezuela. Volumen 2. Fundación Científica Los Roques, Caracas.

Chang, W.Y.B. 1982. A statistical method for evaluating the reproducibility of age determination. Canadian Journal of Fisheries and Aquatic Science, 39: 12081210.

Chao, N.L., Frédou, F.L., Haimovici, M., Peres, M.B., Polidoro, B., Raseira, M., et al. 2015. A popular and potentially sustainable fishery resource under pressureextinction risk and conservation of Brazilian Sciaenidae (Teleostei: Perciformes). Global Ecology and Conservation, 45: 1-10. doi: 10.1016/j.gecco. 2015.06.002

Chaves, P.T. \& Robert, M.C. 2003. Embarcações, artes e procedimentos da pesca artesanal no litoral sul do estado do Paraná, Brasil. Atlântica, 25: 53-59.

Clardy, S.D., Brown-Peterson, N.J., Peterson, M.S. \& Leaf, R.T. 2014. Age, growth, and reproduction of southern kingfish (Menticirrhus americanus): a multivariate comparison with life-history patterns in other sciaenids. Fishery Bulletin National Oceanic and Atmospheric Administration, 112: 1-20. doi: 10.7755/ FB.112.2-3.6

Corrêa, K.M. \& Ávila-da-Silva, A.O. 2016. The dynamics of white mouth croaker fishing by gillnet and pair trawl in Southeastern Brazilian Bight. Latin American Journal Aquatic Research, 44: 1019-1027. doi: 10.3856/vol44-issue5-fulltext-13

Costa, E.F.S., Dias, J.F. \& Murua, H. 2015. Reproductive strategy and fecundity of the keystone species Paralonchurus brasiliensis (Teleostei, Sciaenidae): an image processing techniques application. Environmental Biology of Fishes, 98: 2093-2108. doi:10.1007/ s10641-015-0432-2

Dias, J.F., Fernandez, W.S. \& Schmidt, T.C.S. 2014. Length-weight relationship of 73 fish species caught in the southeastern inner continental shelf region of Brazil. Latin American Journal Aquatic Research, 42: 127-136. doi: 10.3856/vol42-issue1-fulltext-10
Fávaro, L.F., Lopes, S.C.G. \& Spach, H.L. 2003. Reprodução do peixe-rei, Atherinella brasiliensis (Quoy e Gaimard) (Atheriniformes, Atherinidae), em uma planície de maré adjacente à gamboa do Baguaçu, Baía de Paranaguá, Paraná, Brasil. Revista Brasileira de Zoologia, 20: 501-506. doi: 10.1590/S0101-8175 2003000300022

Freire, K.M.F., Tubin, R.A., Monteiro-Neto, C., AndradeTubino, M.F., Belruss, C.G., Tomas, A.R.G., et al. 2016. Brazilian recreational fisheries: current status, challenges and future direction. Fisheries Management and Ecology, 23: 276-290. doi: 10.1111/fme.12171

Freitas, M.O., Previero, M., Minte-Vera, C.V., Spach, H.L., Francini-Filho, R.B. \& Moura, R.L. 2018. Reproductive biology and management of two commercially important groupers in the SW Atlantic. Environmental Biology of Fishes, 101: 79- 94. doi: 10.1007/s10641-017-0682-2

Grupo de Estudos Pesqueiros da UNIVALI (GepUNIVALI). 2019 [www.propesqweb.acad.univali.br]. Reviewed: January 12, 2020.

Giannini, R. \& Paiva-Filho, A.M. 1992. Aspectos da bioecología de Menticirrhus americanus (Teleostei Sciaenidae) na Baía de Santos, São Paulo, Brasil. Boletim do Instituto de Pesca, 19: 1-15.

Godefroid, R.S., Santos, C., Hofstaetter, M. \& Spach, H.L. 2001. Occurrence of larvae and juveniles of Eucinostomus argenteus, Eucinostomus gula, Menticirrhus americanus, Menticirrhus littoralis, Umbrina coroides and Micropogonias furnieri at Pontal do Sul beach, Paraná. Brazilian Archives of Biology and Technology, 44: 411-418. doi: 10.1590/S1516-89132001000 400012

Graça-Lopes, R., Tomás, A.R.G., Tutui, S.L.S., Severino Rodrigues, E. \& Puzzi, A. 2002. Fauna acompanhante da pesca camaroeira no litoral do estado de São Paulo, Brasil. Boletim do Instituto de Pesca, 28: 173-188.

Haimovici, M. \& Mendonça, J.T. 1996. Análise da pesca de peixes e camarões com arrasto de tangones no sul do Brasil - periodo 1989-1994. Atlântica, 18: 143-160.

Haimovici, M., Cardoso, L.G. \& Unpierre, R.G. 2016. Stocks and management units of Micropogonias furnieri (Desmarest, 1823) in southwestern Atlantic. Latin American Journal Aquatic Research, 44: 10801095. doi: 10.3856/vol44-issue5-fulltext-18

Haimovici, M., Freire, M.A., Fischer, L. \& Conceição, W.V. 2005. Abundância relativa e tamanhos de teleósteos e cefalópodes em águas costeiras da Plataforma Sul. In: Vooren, C.M. \& Klippel, S. (Eds). Ações para a conservação de tubarões e raias no sul do Brasil. Igaré, Porto Alegre, pp. 121-127. 
Haluch, C.F., Freitas, M.O., Corrêa, M.F.M. \& Abilhoa, V. 2009. Variação sazonal e mudanças ontogênicas na dieta de Menticirrhus americanus (Linnaeus, 1758) (Teleostei, Sciaenidae) na baía de Ubatuba-Enseada, Santa Catarina, Brasil. Pan-American Journal of Aquatic Sciences, 4: 347-356.

Haluch, C.F., Abilhoa, V., Freitas, M.O., Corrêa, M.F.M. \& Hostim-Silva, M. 2011. Estrutura populacional e biologia reprodutiva de Menticirrhus americanus (Linnaeus, 1758) (Teleostei, Sciaenidae) na baía de Ubatuba-Enseada, Santa Catarina. Biotemas, 24: 4759.

Herrema, D.J., Peery, B.D., Williams-Walls, N. \& Wilcox, J. 1985. Spawning periods of common inshore fishes on the Florida East Coast. Northeast Gulf Science, 7: 4.

Huxley, J.S. 1929. Constant differential growth-ratios and their significance. Nature, 14: 896-897.

Instituto Chico Mendes de Conservação da Biodiversidade (ICMBIO). 2019. [www.icmbio.gov.br/]. Reviewed: January 12, 2020.

King, M. 1995. Fisheries biology: assessment and management. Fishing Books News, Oxford.

Lana, P.C., Marone, E., Lopes, R.M. \& Machado, E.C. 2001. The Subtropical Estuarine Complex of Paranaguá Bay, Brazil. In: Seeliger, U. \& Kjerfve, B. (Eds.). Coastal marine ecosystems of Latin America. Series Ecological Studies, 144: 131-145. doi: 10.1007/ 978-3-662-04482-711

Lowerre-Barbieri, S.K., Burnsed, S.L.W. \& Bickford, J.W. 2016. Assessing reproductive behavior important to fisheries management: a case study with red drum, Sciaenops ocellatus. Ecological Applications, 26: 979995. doi: 10.5061/dryad.47bs5

Maciel, T.R., Vaz-dos-Santos, A.M. \& Vianna, M. 2018. Can otoliths of Genidens genidens (Cuvier 1829) (Siluriformes: Ariidae) reveal differences in life strategies of males and females? Environmental Biology of Fishes, 101: 1589-1598. doi: 10.1007/ s10641-018-0804-5

McDowell, D.E. \& Robillard, E. 2013. Life history characteristics and age validation of southern kingfish (Menticirrhus americanus (Linnaeus, 1758)) in the middle South Atlantic Bight. Journal Applied of Ichthyology, 29: 839-846. doi: 10.1111/jai.12198

Menezes, N.A., Buckup, P.A., Figueiredo, J.L. \& Moura, R.L. 2003. Catálogo de espécies de peixes marinhos do Brasil. Museu de Zoologia da Universidade de São Paulo, São Paulo.

Menezes, N.A. \& Figueiredo, J.L. 1980. Manual de peixe marinhos do sudeste do Brasil Teleostei I. Museu de Zoologia, Universidade de São Paulo, São Paulo, 3: 42-59.
Militelli, M.I., Macchi, G.J. \& Rodrigues, K.A. 2012. Comparative reproductive biology of Sciaenidae family species in the Rio de la Plata and Buenos Aires Coastal Zone, Argentina. Journal Marine Biological Association of the United Kingdom, 93: 413-423. doi: 10.1017/S0025315412001488

Muniz, E.R. \& Chaves, P.T. 2008. Condição reprodutiva da betara preta, Menticirrhus americanus (Teleostei, Sciaenidae), na pesca realizada no litoral norte de Santa Catarina, Brasil. Acta Scientarium Biological Science, 30: 339-344. doi: 10.4025/actascibiolsci. v30i4.1230

Nelson, G.A. 2017. Fishery science methods and models in R. [https://rdrr.io/cran/fishmethods/]. Reviewed: January 12, 2020.

Ogle, D.H. 2015. Introductory fisheries analyses with R. Chapman \& Hall/CRC, Boca Raton.

Passos, A.C., Schwarz, J.R., Cartagena, B.F.C., Garcia, A.S. \& Spach, H.L. 2012. Weight-length relationship of 63 demersal fishes on the shallow coast of Paraná, Brazil. Journal of Applied Ichthyology, 28: 845-847. doi: 10.1111/j.1439-0426.2012.01973.x

Pita, A., Casey, J., Hankins, S.J., Villarreal, M.R., Gutiérrez, M.J., Cabral, H., et al. 2015. Conceptual and practical advances in fish stock delineation. Fisheries Research, 173: 185-193. doi: 10.1016/j.fishres.2015. 10.029

Possamai, B. \& Fávaro, L.F. 2015. Using mariculture as a breeding site: reproduction of Hypleurochilus fissicornis (Actinopterygii: Blenniidae). Scientia Marina, 79: 335-343. doi: 10.3989/scimar.04176.19B

Possamai, B., Zanlorenzi, D., Machado, R.C. \& Fávaro, L.F. 2018. Length-weight relationships for estuarine fishes in south Brazil. Journal of Applied Ichthyology, 35: 608-613. doi: 10.1111/jai.13846

Rondineli, G.R., Braga, F.M.S., Tutui, S.L.S. \& Bastos, G.C. 2007. Dieta de Menticirrhus americanus (Linnaeus, 1758) e Cynoscion jamaicensis (Vaillant e Bocourt, 1883) (Pisces, Sciaenidae) no sudeste do Brasil, Estado de São Paulo. Boletim do Instituto de Pesca, 33: 221-228.

Santos, L.O., Cattani, A.P. \& Spach, H.L. 2016. Ictiofauna acompanhante da pesca de arrasto para embarcações acima de 45 HP no litoral do Paraná, Brasil. Boletim do Instituto de Pesca, 42: 816-830.

Santos, R.S., Costa, M.R. \& Araújo, G.F. 2017. Age and growth of the white croaker Micropogonias furnieri (Perciformes: Sciaenidae) in a coastal area of Southeastern Brazilian Bight. Neotropical Ichthyology, 15: 1-12. doi: 10.1590/1982-0224-20160131

Santos, R.S., Silva, J.P.C., Costa, M.R. \& Araújo, G.F. 2015. O tamanho de primeira maturação como parâmetro para o estabelecimento de tamanho mínimo 
de captura para corvina no sudeste do Brasil. Boletim do Instituto de Pesca, 41: 507-518.

Soeth, M., Fávaro, L.F., Spach, H.L., Daros, F.A., Woltrich, A.E. \& Correia, A.T. 2018. Age, growth, and reproductive biology of the Atlantic spadefish Chaetodipterus faber in southern Brazil. Ichthyological Research, 211: 81-90. doi: 10.1007/s10228018-0663-2

Souza, L.M. \& Chaves, P.T. 2007. Atividade reprodutiva de peixes (Teleostei) e o defeso da pesca de arrasto no litoral norte de Santa Catarina, Brasil. Revista Brasileira de Zoologia, 24: 1113-1121. doi: 10.1590/ S0101-81752007000400031

Souza, M.R., Carneiro, M.H., Quirino-Duarte, G. \& Servo, G.J.M. 2007. Caracterização da "mistura" na pesca de arrasto-de-parelha desembarcada em Santos e Guarujá, São Paulo, Boletim do Instituto de Pesca, 33: 43-51.

Spalding, M.D., Fox, H.E., Allen, G.R., Davidson, N., Ferdaña, Z.A., Finlayson, M., et al. 2007. Marine ecoregions of the world: a bioregionalization of coastal and shelf areas. BioScience, 57: 573-584. doi: 10.1641/B570707

Taylor, C.C. 1959. Temperature and growth - the Pacific razor clam. ICES Journal of Marine Science, 25: 93101. doi: 10.1093/icesjms/25.1.93

Received: 10 July 2020; Accepted: 5 November 2020
Turra, A., Santos, F.B., Bessa, E., Fernandez, W.S., Bernadochi, L.C. \& Denadai, M.R. 2012. Population biology and diet of the southern kingcroaker Menticirrhus americanus (Linnaeus, 1758) (Perciformes: Sciaenidae) in Caraguatatuba Bay, southeastern Brazil. Brazilian Journal Oceanography, 60: 343-252. doi: 10.1590/S1679-87592012000300007

Vaz-dos-Santos, A.M. \& Gris, B. 2016. Length-weight relationships of the ichthyofauna from a coastal subtropical system: a tool for biomass estimates and ecosystem modelling. Biota Neotropical, 16: 1-6. doi: 10.1590/1676-0611-BN-2016-0192

Vaz-dos-Santos, A.M. \& Rossi-Wongtschowski, C.L.D.B. 2007. Age and growth of the Argentine hake Merluccius hubbsi Marini, 1933 in the Brazilian southsoutheast region during 1996-200. Neotropical Ichthyology, 3: 375-386. doi: 10.1590/S1679-6225200 7000300017

Vazzoler, A.E.A.M. 1996. Biologia da reprodução de peixes teleósteos: teoria e prática. EDUEM, Maringá.

Von Bertalanffy, L. 1938. A quantitative theory of organic growth (inquiries on growth laws). Human Biology, 10: 79-102. doi: $10.2307 / 41447359$ 